Review

\title{
European National Road Authorities and Circular Economy: An Insight into Their Approaches
}

\author{
Konstantinos Mantalovas ${ }^{1, * \mathbb{D}}$, Gaetano Di Mino ${ }^{1}$, Ana Jimenez Del Barco Carrion ${ }^{2}$, \\ Elisabeth Keijzer ${ }^{3}$, Björn Kalman ${ }^{4}$, Tony Parry ${ }^{5}$ (1) and Davide Lo Presti ${ }^{1,5, *}$ \\ 1 Department of Engineering, University of Palermo, 90128 Palermo, Italy; gaetano.dimino@unipa.it \\ 2 Department of Construction Engineering and Engineering Projects, University of Granada, \\ 18003 Granada, Spain; ajbc@ugr.es \\ 3 Netherlands Organization for Applied Scientific Research (TNO), 3584 CB Utrecht, The Netherlands; \\ elisabeth.keijzer@tno.nl \\ 4 Swedish National Road and Transport Research Institute (VTI), 58330 Linkoping, Sweden; \\ bjorn.kalman@vti.se \\ 5 Nottingham Transportation Engineering Centre (NTEC), University of Nottingham, \\ Nottingham NG7 2RD, UK; tony.parry@nottingham.ac.uk \\ * Correspondence: konstantinos.mantalovas@unipa.it (K.M.); davide.lopresti@unipa.it or \\ davide.lopresti@nottingham.ac.uk (D.L.P.); Tel.: +44-746-0705-153 or +39-391-7494-647 (K.M.); \\ +44-758-7140-422 (D.L.P.)
}

Received: 30 July 2020; Accepted: 1 September 2020; Published: 2 September 2020

check for updates

\begin{abstract}
The pavement engineering industry, having realized the significance of the impacts that it imposes on the environment through the production, construction and management of its products and assets, has been driven towards a more sustainable and circular way of operating. This has partly been through asphalt recycling, which is an area that many road authorities have prioritized. However, not all the National Road Authorities (NRAs) and/or sector stakeholders seem to be adequately familiar with the Circular Economy (CE) concept. This paper attempts to assist the transition of NRAs to a more circular way of doing business, by analyzing the current situation of CE within national/regional authorities and NRAs. To do so, a questionnaire was sent to different NRAs and an online search was conducted to identify the ways that NRAs communicate their CE practices. Findings indicate that, although the majority of the NRAs are familiar with CE as a concept, not many actions have been taken so far towards its holistic implementation. Finally, there is a significant lack of CE expertise and communication within these bodies.
\end{abstract}

Keywords: circular economy; asphalt pavements; National Road Authorities; circular procurement; circular recommendations; circular road maps

\section{Introduction}

The debate about future availability of natural resources remains a center of attention. Growing amounts of natural, non-renewable resources are being exploited to fulfil the needs of industries [1,2]. This leads to severe environmental, social, and of course, economic impacts, that disturb the desirable equilibrium between the three pillars of sustainability, as first proposed by Barbier in 1987 [3,4]. According to the Roadmap to a Resource Efficient Europe (RERM), better construction and use of built infrastructure could help in achieving significant resource savings: it could influence $42 \%$ of our final energy consumption and about $35 \%$ of our total greenhouse gas (GHG) emissions, 50\% of extracted materials, and it could save up to $30 \%$ of water in some regions, when considering the construction industry $[5,6]$. Since transportation infrastructures-and road pavements in particular-represent one of the largest parts of the built infrastructure, their contribution to energy and water consumption, 
the extraction of virgin materials and the emission of GHGs is significant. A promising concept that has lately re-emerged and pledges to improve the situation and/or relax the pressures on the environment, society and economy, is the concept of Circular Economy (CE). Although there is not a consensual and definitive definition of $\mathrm{CE}$, one of the most widely accepted definitions is that of the Ellen MacArthur Foundation (EMF): "economy that is restorative and regenerative by design, and which aims to keep products, components, and materials at their highest utility and value at all times, distinguishing between technical and biological cycles" [7-9]. Two different types of products can be identified: products that, after their lifecycle, can either return into the technical cycle (durables), or into the biological cycle (consumables) [7,8]. It could potentially provide an answer to increasing resource consumption because it aims to transform the function of resources in an economy [10-14]. This paper, thus, presents the findings of research to answer questions about the familiarity, knowledge, implementation, and communication of Circular Economy by National Road Authorities:

- How do NRAs realize their transition to more circular approaches?

- How do NRAs implement and communicate their approaches on CE?

Within the paper, firstly, in Chapter 2, a brief background of the CE is presented. It revolves around $\mathrm{CE}$, asphalt production and use under the light of $\mathrm{CE}$, and the implementation of circular economy principles in road construction and maintenance. Secondly, in Chapter 3, the methods used for the research are explained distinguishing between three different approaches. The analysis of national/regional authority roadmaps towards CE that have been published through the European CE Stakeholder Platform, the questionnaire about $\mathrm{CE}$ and its implementation and completion by National Road Authorities (NRAs) across Europe, and a web search in the official websites of the investigated NRAs in order to identify aspects of communication concerning CE. In Chapter 4, the results obtained and their analysis are presented and finally, in Chapter 5, a brief discussion along with the conclusions of the research conducted can be found.

\section{Literature Review}

\subsection{Circular Economy}

One of the first publications that successfully managed to raise awareness about the issue of overloading the Earth's natural sinks (where ecosystems receive pollutants or wastes) and overexploiting resources, was the report of Meadows et al. (1972), "The Limits to growth", for the Club of Rome. The broader public was confronted with the thought that only limited growth is possible on a finite planet with finite resources [15]. The model proposed by Meadows and colleagues studied the interactions between pollution, population, consumption of non-renewable resources, regeneration rates of renewable resources, food, and industrial output. According to their scenarios, system "failure" occurs due to pollution, even though society would have been able to effectively manage to conserve non-renewable resources [15]. However, Lomborg questioned the objectivity and accuracy of the Meadows model, arguing that human ingenuity and the strength of innovations were not taken into consideration [16]. A philosophy or concept that encompasses innovation and innovative business models at its' core, is the Circular Economy. It is a concept that made its first appearance as a proactive policy goal for numerous businesses and in political agendas in the late 1970s, mainly due to climate change and the acute concern of rising resource prices, raised by Carson and Boulding [8,17-20].

Moreover, following this definition, the EMF supports the norm of thinking in systems and cascades. Adopting systemic thinking and a cascade approach, end-products, components and even materials can be repurposed, reutilized, recycled or have their service life extended while keeping their highest value. These principles and their beneficial implementation are analyzed in several publications of the Ellen MacArthur Foundation. Another aspect that is mentioned and also represents a core pillar of $C E$, is the utilization of renewable resources [21-24]. Moreover, as discussed in the publication of Mark J. Goedkoop et al. from 1999, that was commissioned by the Dutch ministries of Environment (VROM) and Economic Affairs (EZ), the concept of CE is opting to provide a "marketable 
set of products and services capable of jointly fulfilling a user's needs" and not just end products, solely to be sold to consumers $[25,26]$. This concept encompasses the principles of multiple schools of thought, such as "industrial ecology and symbiosis", "performance economy", "biomimicry", "cradle to cradle", "blue economy", "regenerative design", "cleaner production", and "natural capitalism" [27,28]. Circular economy is a type of economy that integrates principles and approaches originating from all the different types of philosophies/approaches. Some of these proposals date back to 1970 and the constant evolution of different approaches, with a similar end goal, has developed since. CE was first mentioned in 1990 by Pearce and Turner who also modelled it [29]. The main schools of thought that have contributed to shaping the current philosophy of CE can be seen in Figure 1.

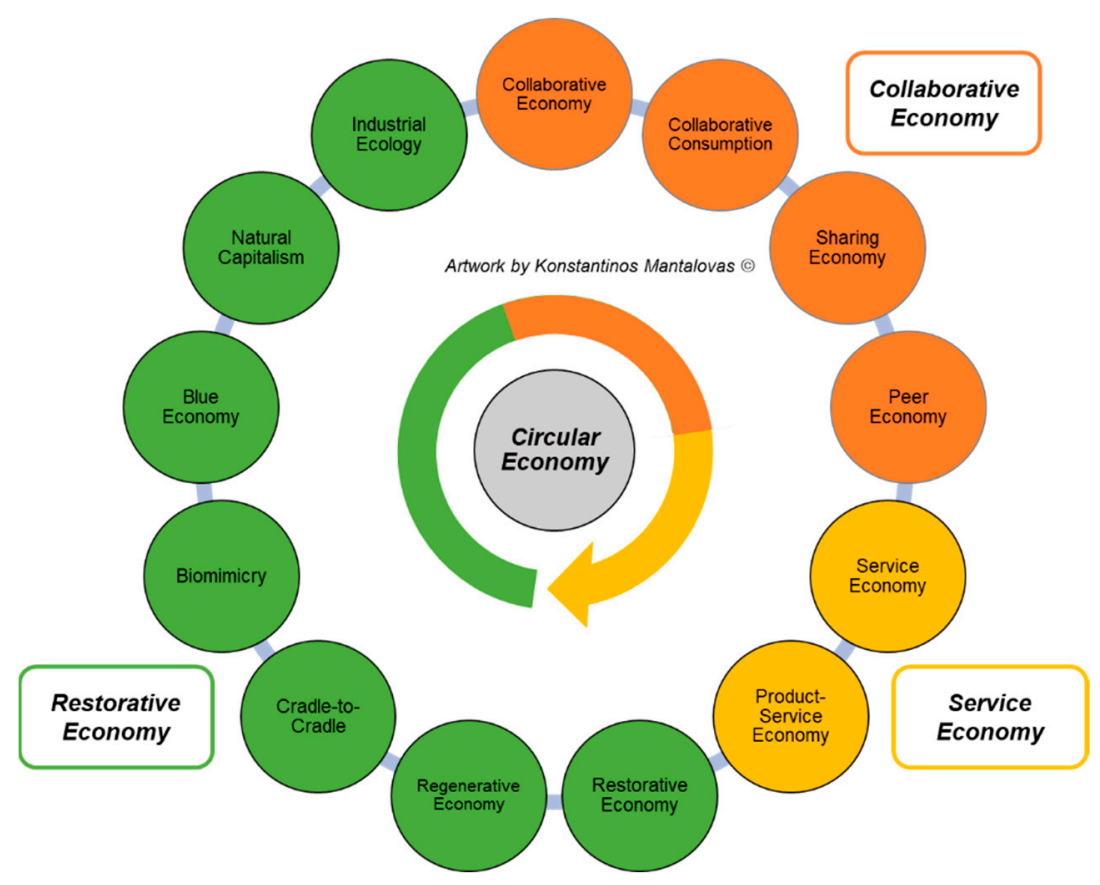

Figure 1. Schools of thought and economic approaches forming the philosophy of Circular Economy (CE).

Service Economy is the type of economy in which retailers and manufacturers can maintain the ownership of their products and become "service providers" [30,31]. The Service Economy supports the transition of procurement patterns from product purchasing to service purchasing. The consumer becomes a user, who pays for using a specific product instead of owning it. The term refers to an economic model where the importance is placed on services and the majority of jobs are in service activities. By changing this economic pattern, the service provider not only has an incentive to cut down the resource expenditure but also to reduce the energy consumption in the production process $[14,32]$.

Collaborative Economy is a type of economy that has been decentralized and contains networks of individuals and communities instead of institutions. This type of economy aims to change the way of current production, consumption, finance and education [14,33]. Different expressions that could describe this type of economy are "sharing economy/peer economy" or "collaborative consumption". In the context of this type of economy, inventors and investors are brought together in order to compile the full procedure of sharing, selecting, producing and distributing new products. Moreover, the utilization of products through redistribution or shared access is a representative paradigm of this type of economy. Thus, the three main aspects of a collaborative economy can be described as $[7,14,33]$ the shift of power away from institutions towards networks of individual actors, the innovative and efficient product utilization, and technological innovation, shifting values, economic realities and environmental pressure being the main drivers. Restorative Economy or "regenerative economy" represents a type of economy that implies the need for creation of a new type of relationship between the industrial systems and the ecosystems. This type of economy is able to copy and integrate 
the mechanisms of nature within the industrial systems in order to restore the natural environment instead of degrading it. Products in the context of this economy should be designed so as to be able to be reused as material inputs to another system's lifecycle or to be easily deconstructed and reused or maintained with an ultimate goal of increasing biodiversity and not the opposite [14,34]. Other similar approaches that have also been inspired by nature are: "cradle to cradle", "biomimicry", "blue economy", "industrial ecology" and "natural capitalism" [32,35-43].

The CE contains aspects of all three alternative economic models mentioned above. However, the concept distinguishes itself by focusing on the circularity of resources and the avoidance of waste.

\subsection{Circular Economy, Asphalt Production and Use}

So far, common practices that various stakeholders, companies, asphalt contractors and agencies are implementing in line with the principles of CE are the recycling of reclaimed asphalt (RA), the extension of the service life of their assets (preventive maintenance), and the use of wastes in asphalt pavements. The use of RA for the production of asphalt mixtures can lead to positive overall environmental and economic impacts while maintaining an equivalently acceptable technical performance for the asphalt pavements [44], as previous studies have shown [45,46]. In detail, a mixture that is asphalt-based and incorporates RA contains less bituminous binder and virgin aggregates in comparison to a conventional asphalt mixture. Hence, the environmental impacts are reduced, and the energy demand can be decreased in certain cases by $23 \%$, in comparison to conventional Hot Mix Asphalt mixtures [44,47-50]. Asphalt recycling and preventive maintenance though, are sometimes implemented not because they serve the principles of CE and are beneficial in terms of sustainability, but because they are economically beneficial and by the rule of thumb are considered as best practices. Again, nothing has been published in terms of asphalt pavements when it comes to legislative guidelines towards more 'circular' pavements. This has not stopped some individual stakeholders moving in this direction. KRATON for example has moved forward by producing SYLVAROAD ${ }^{\mathrm{TM}} \mathrm{RP1000}$, a pine chemical additive derived from Crude Tall Oil (CTO), a renewable raw material characterized as a by-product of the paper industry. Its use can increase the levels of RA that can be incorporated into asphalt mixtures, while avoiding significant environmental burdens associated with $\mathrm{CO}_{2}$ emissions and virgin material utilization [8,51]. Another noteworthy attempt towards more circular products has been made by Tarpaper Recycling, along with Super Asfalt, that have proposed the production of REC100. This is a mobile asphalt plant that allows $100 \%$ utilization of the resources in roofing felt and asphalt waste, in order to produce asphalt mixtures incorporating $100 \%$ recycled resources.

Unfortunately, though, the effort of the pavement engineering industry towards more circular and sustainable products is not yet thriving. As circular economy has been proven to contribute to sustainability [52], more circular attempts by the pavement engineering industry should be made in this direction if their intention is to become more circular and sustainable. The extension of the application of the CE principles to an asset, such as road pavement, is a rather recent action, particularly within the development of pavement management systems [53]. Only in recent years has the world of scientific research begun dealing with the issue of the implementation of the CE in the production and treatment processes of asphalt in the road construction industry [9]. Under the light of CE and for the pavement engineering sector, the recycling of reclaimed asphalt can be characterized as one of the most circular practices. In other words, asphalt recycling is the most common type of recycling that takes place within the road engineering industry $[8,54]$ and can deliver significant environmental and economic benefits. NRAs also incorporate into asphalt pavements other recyclable materials such as steel slag, concrete, glass, etc., but RA is the most common choice amongst them due to the fact that it can be recycled into pavement that performs as well as, or even better than, pavements made of all-virgin materials $[55,56]$. Moreover, the same material can be recycled again and again; it never loses its value. The asphalt binder retains its function so that it is reused for its original purpose. The aggregates (rocks, sand, and gravel) in the original pavement are also conserved $[57,58]$. 


\subsection{Implementation of Circular Economy Principles in Road Construction and Maintenance}

Policies that encourage the implementation of the principles of $C E$ have already been introduced in some cases. The European Commission, responding to the increasing pressures on natural resources launched the European Resource Efficiency Platform (EREP) in 2012, with a manifesto and policy recommendations that were adopted in Brussels on the 17th of December 2012. The European Resource Efficiency Platform called on business, labor and civil society leaders to support resource efficiency and the move to a circular economy [59]. The target was to move towards a harmonized and controlled transition from linear economic patterns to circular ones. As described in the published manifesto, the desirable approach would be a transition towards a resource efficient and ultimately restorative CE. After the foundation of the aforementioned platform, which is composed of practitioners and politicians, guidelines have been publicly provided, in order for the implementation of "circular economy(-friendly)" approaches and frameworks to be widely adopted and finally implemented [5,59].

The United Kingdom acting as a pioneer in this context was the first European country to publish standards about the implementation of CE in 2017 [28]. France followed with the development of voluntary standards called XP X30, published by the French Association for Standardization (ANFOR) in 2018 [60]. The title is "Circular economy-Circular economy project management system-Requirements and guidelines" and the standards propose a common understanding grid, laying out the terms, principles, and practices relevant to CE. The development of these standards led to the creation of a technical committee within the International Organization for Standardization (ISO TC 323) which is working on enriching and developing international standards in the CE field. The proposed deliverables will apply to any organization or group of organizations wishing to implement CE projects, such as commercial organizations, public services, and not-for-profit organizations. Specifications relevant to already covered and standardized aspects such as eco-design, life cycle assessment, environmental management and sustainable procurement will not be included in the standards.

Moreover, in July 2019, Platform CB'23 from The Netherlands published a framework for circular construction, focusing on building works. The requirements for a uniform measurement method of circularity are emphasized and an approach for quantifying circularity is proposed [61]. Finally, the European Union, understanding the necessity for CE, had officially adopted an action plan in 2015 to help accelerate Europe's transition towards a CE, boost global competitiveness, promote sustainable economic growth and generate new jobs and in 2019 the Circular Economy Action Plan was completed [62].

The European Commission has invested in CE and sustainability in every sector. For the pavement engineering, and road construction and maintenance sectors, a technical report was published in 2016 [63], detailing the practices that NRAs and involved stakeholders should be implementing for more sustainable and circular approaches. Moreover, a set of criteria has been developed, that can help stakeholders act immediately even without having a deep knowledge of CE and sustainability. The EU commission has identified some of the most impactful stages and aspects of a road's lifecycle that when modified accordingly can be significantly beneficial for the environment and the economy, based on the principles of green procurement and CE. The most relevant stages/aspects identified that can be immediately applicable for increased circular performances are:

- Resource efficient construction.

- Recycled content: high percentages of materials are recycled into asphalt pavements, while complying with the performance requirements for the road pavement.

- Excavated materials, soil, and wastes management: excavated materials, soils and wastes that are not hazardous can be reused on site.

- Water and habitat conservation: road drainage systems must adequately drain both stormwater from the road surface and sub-surface water from groundwater flows. Moreover, it is suggested that Sustainable Drainage Systems (SUDS) are promoted in an attempt to re-use the drained water. 
- Maintenance and rehabilitation strategies: a Maintenance \& Rehabilitation Plan, that considers all the aforementioned suggestions, should be developed during detailed design.

The European Commission has also published a document entitled "Circular Economy: Principles for Buildings Design" [64] that details the general principles that should be implemented if a more circular approach is to be adopted in the building sector. The document is specifically focused on buildings, but the main principles are presented here because of the similarities that exist between buildings and roads.

- Better knowledge is needed about construction techniques to facilitate deconstruction and to enhance durability and adaptability of built assets.

- Durability depends on better design, improved performance of construction products and information sharing.

- Prevent premature asset demolition by developing a new design culture.

- Design products and systems so that they can be easily reused, repaired, recycled, or recovered.

While these principles refer to buildings, they can easily and immediately be applied to other built assets such as road pavements, thus assisting the road engineering industry as well.

The road engineering industry, by taking under consideration the aforementioned recommendations/suggestions, could potentially improve its environmental performance and sustainability levels while increasing its circularity.

\section{Methods}

Firstly, after presenting a brief background of the CE, the implementation of circular economy principles in the construction and maintenance of roads is presented. Secondly, the national/regional authority roadmaps towards CE that have been published through the European CE Stakeholder Platform are analyzed. Thirdly, a questionnaire about CE and its implementation (NRAs) that was distributed to different NRAs across Europe, is analyzed. In addition, an online research has been conducted via the official websites of the investigated NRAs in order to identify aspects of communication concerning CE. The words "circular economy" and "sustainability" were searched for on the websites and the results were analyzed. When it comes to transport infrastructures and asphalt pavements specifically, it becomes difficult to encompass and conceptualize all these principles in their life cycles. Indeed, there is a plethora of roadmaps towards CE that have been published attempting to pave the way towards achieving circularity at national level but not a lot of effort has been made to specifically address the sector of road engineering. In this study we have identified what has been published by national and/or regional authorities for the road engineering sector that can be implemented towards more circular operational patterns. In Table 1, all the national plans and/or roadmaps published online through the European CE Stakeholder Platform can be found, along with the single roadmap produced by an NRA (Highways England). It is worth mentioning that only the roadmaps published in English were analyzed. Thus, the documents C: Regional plan for the circular economy, Brussels Capital Region, M: Extremadura 2030, N: Strategy of the government of Catalonia: Promoting green and circular economy in Catalonia, O: Circular the Hague: transition to a sustainable economy, were not analyzed. The documents were analyzed according to the criteria of whether or not they present targets, goals, best practices and/or recommendations towards the transition of the road and pavement engineering industry to a more circular way of conducting business. The weight was given to the development of transportation infrastructures and more specifically of asphalt pavements. Moreover, mentions of the building sector that can be immediately applicable to the production of asphalt mixtures, the construction, use, and maintenance of asphalt pavements were taken under consideration. 
Table 1. National plans and/or roadmaps published online through the European CE Stakeholder Platform (https://circulareconomy.europa.eu/platform/en/strategies?page=1).
A. The Danube goes Circular-Transnational Strategy to Accelerate Transition Towards a Circular Economy in the Danube Region (ENGLISH) [65]

Austria, Bulgaria, Croatia, Czech Republic, Germany, Hungary, Romania, Slovak Republic, Slovenia, Ukraine, Moldova, Serbia, Montenegro, Bosnia and Herzegovina

\begin{tabular}{|c|c|c|}
\hline B. & Circular Flanders kick-off statement (ENGLISH) [66] & Belgium \\
\hline C. & $\begin{array}{l}\text { Regional plan for the circular economy, Brussels Capital Region } \\
\text { (DUTCH, FRENCH) [67] }\end{array}$ & Belgium \\
\hline D. & $\begin{array}{l}\text { Leading the cycle-Finnish road map to a circular economy 2016-2025 } \\
\text { (ENGLISH) [68] }\end{array}$ & Finland \\
\hline E. & 50 Measures for a 100\% Circular Economy (ENGLISH) [69]. & France \\
\hline F. & German Resource Efficiency Programme II (ENGLISH) [70]. & Germany \\
\hline G. & National Action Plan on Circular Economy (ENGLISH) [71] & Greece \\
\hline H. & $\begin{array}{l}\text { Towards a Model of Circular Economy for Italy-Overview and } \\
\text { Strategic Framework (ENGLISH) [72] }\end{array}$ & Italy \\
\hline A. & $\begin{array}{l}\text { Luxembourg as a knowledge capital and testing ground for the } \\
\text { Circular Economy (ENGLISH) [73] }\end{array}$ & Luxemburg \\
\hline A. & $\begin{array}{l}\text { Leading the transition: a circular economy action plan for Portugal } \\
\text { (ENGLISH) [74] }\end{array}$ & Portugal \\
\hline B. & $\begin{array}{l}\text { Strategy for the Transition to the Circular Economy in the } \\
\text { Municipality of Maribor (ENGLISH) [75] }\end{array}$ & Slovenia \\
\hline C. & Roadmap towards the Circular Economy in Slovenia (ENGLISH) [76] & Slovenia \\
\hline D. & Extremadura 2030 (SPANISH) [77] & Spain \\
\hline E. & $\begin{array}{l}\text { Strategy of the government of Catalonia: Promoting green and } \\
\text { circular economy in Catalonia (SPANISH/CATALAN) [78] }\end{array}$ & Spain \\
\hline F. & Circular the Hague: transition to a sustainable economy (DUTCH) [79] & The Netherlands \\
\hline G. & A Circular Economy in the Netherlands by 2050 (ENGLISH) [80] & The Netherlands \\
\hline H. & $\begin{array}{l}\text { Kernmethode voor het meten van circulariteit in de bouw } \\
\text { (DUTCH/ENGLISH) [61] }\end{array}$ & The Netherlands \\
\hline I. & Making Things Last: a circular economy for Scotland (ENGLISH) [81] & United Kingdom \\
\hline $\mathrm{J}$. & London's Circular Economy Route Map (ENGLISH) [82] & United Kingdom \\
\hline K. & Circular Economy Approach and Routemap * (ENGLISH) [83] & United Kingdom \\
\hline
\end{tabular}

\subsection{Questionnaire to National Road Authorities}

Furthermore, in order to focus the research on the field of pavement and road engineering, agencies such as National Road Authorities were under the focal point of the study. The NRAs of different European countries were contacted in order to identify if they are familiar with CE and how they are implementing it. Consequently, a questionnaire was formulated mostly relevant to their sustainability assessment approaches, since they were part of the Pavement LCM project (https://www.pavementlcm.eu/), funded by the Conference of European Directors of Roads (CEDR) and focusing on the life cycle management and sustainability assessment approaches that NRAs could adopt. However, the survey was structured in a manner which was able to provide a qualitative analysis through the questions that can be found in the Appendix A, which are relevant to the CE and were also included to the questionnaire for a more spherical overview. A plethora of European NRAs is 
in partnership with the funding body, CEDR; thus, most of these NRAs were contacted through email and the ones interested in participating replied. The data and results presented in this paper include all the NRAs that have filled in the questionnaire. It was filled openly by up to 2 persons working within the corresponding NRAs in positions closely related to sustainability and/or sustainability development and assessment. The questionnaire was filled by the NRAs given below.

- $\quad$ Austria (ASFiNAG)

- Denmark (Danish Road Directorate-Vejdirektoratet)

- Germany (Federal Ministry of Transport, Building and Urban Development-Bundesministerium für Verkehr und digitale Infrastruktur)

- United Kingdom (Highways England, Transport Scotland, Welsh Government, Roads Service)

- Lithuania (Lithuanian Road Administration and family of road engineers)

- Norway (Norwegian Public Roads Administration-NPRA)

- Slovenia (Slovenian Roads \& Infrastructure Agency)

- Sweden (Swedish Transport Administration Trafikverket)

- Netherlands (Rijkswaterstaat, State advisors for urban development \& infrastructure)

The questionnaire can be found in Appendix A.

\subsection{Web Search: NRAs and CE Communication}

Having structured the questionnaire to reflect whether or not the NRAs are familiar with the CE and if they are implementing it, the next step was to identify whether or not the NRAs also move towards communicating their circular practices, and in general the ways that they implement or plan to implement the CE; since communication of an organization's values can often have a significantly positive impact and value. Hence, in order to identify the ways that NRAs communicate $C E$, an online search was undertaken specified under a textual web search query. The search was conducted online in English and also in the corresponding local language of every investigated NRA, respectively. The official websites of the NRAs that participated in the survey were identified and afterwards, in their "search" function, the words "circular economy" and "sustainability" were searched. The key words were selected in a way that could cover a wide spectrum of CE. Results such as reports and initiatives were reviewed with an end goal to clearly identify how the aforementioned NRAs are trying to communicate to the broader public their commitment to the $\mathrm{CE}$, and what they are doing to integrate circular practices in their operational approaches. The websites of the NRAs that were investigated and the outcomes of the web search, can be found in Section 4.3.

\section{Results and Analysis}

\subsection{Analysis of Roadmaps Produced by National/Regional Authorities towards Circular Economy}

Analyzing the documents collected from the European Circular Economy Stakeholder Platform, it becomes obvious that the principles of CE within the transportation sector are not well established yet. It is worth mentioning that only one of the analyzed documents has been published by an NRA, i.e., Highways England, while the rest have been published by governmental bodies, ministries, companies and/or groups and platforms formed to promote circular thinking. Not all of them deliver a specific set of strategic actions and indicators, metrics, or desirable targets to be reached. In detail, the most common elements of the aforementioned road maps, which include aspects of the pavement engineering industry can be seen in Table 2 . 
Table 2. Summary of the approaches, strategies, and indicators directly applicable to asphalt pavements originating from the analyzed documents.

\begin{tabular}{|c|c|}
\hline Highways England (UK) & $\begin{array}{l}\text { - A detailed plan is deployed until 2025, including the aspects of } \\
\text { governance, procurement, monitoring and reporting and the } \\
\text { development of tools and guidelines. } \\
\text { Potential indicators: material use/km of road built, material use in } \\
\text { schemes, financial performance, savings, and the content of materials } \\
\text { purchased, used and recycled. } \\
\text { - Significant weight given to communication, monitoring and reporting. }\end{array}$ \\
\hline $\begin{array}{l}\text { Platform CB23 } \\
\text { (The Netherlands) }\end{array}$ & $\begin{array}{l}\text { - One of the most analytical and comprehensive approaches towards the } \\
\text { implementation of CE within the construction sector. } \\
\text { - Focuses on the built environment. } \\
\text { Describes "passports for construction", a digital representation of } \\
\text { construction works and the value that than can be created with } \\
\text { these data. } \\
\text { Life Cycle Assessment is coupled with the creation of a passport and } \\
\text { the metrics of alternative passports are compared. } \\
\text { - Approach to quantify the material circularity index of construction } \\
\text { - } \text { Quaterials and processes. } \\
\text { - Influence on the quality of the environment. } \\
\text { Quantity of existing value used, value available for next cycle, existing } \\
\text { value lost. }\end{array}$ \\
\hline $\begin{array}{c}\text { German Resource Efficiency } \\
\text { Programme II }\end{array}$ & $\begin{array}{l}\text { - Utilization of secondary materials for asphalt and concrete pavements. } \\
\text { - Calculation of the reclaimed asphalt percentage that is used in paving } \\
\text { activities, and the percentage of recycled aggregate used as concrete } \\
\text { aggregate relative to total volume of recycled construction materials. } \\
\text { - Minimization of the cumulative raw material consumption and } \\
\text { cumulative energy expenditure in roadbuilding by maximizing the } \\
\text { recycling rates of asphalt. } \\
\text { Raw material productivity (Economic indicator): Promote sustained, } \\
\text { inclusive and sustainable economic growth, full and productive } \\
\text { employment and decent work for all via resource conservation and } \\
\text { using resources economically and efficiently (total raw material } \\
\text { productivity = (GDP+ imports)/raw material input). }\end{array}$ \\
\hline $\begin{array}{c}50 \text { Measures for a } 100 \% \\
\text { Circular Economy (France) }\end{array}$ & $\begin{array}{l}\text { - } \quad \text { Key objectives and measures for better production, consumption, } \\
\text { - } \quad \text { Increased use of secondary materials. } \\
\text { - } \quad \text { Uptake of product-service systems. } \\
\text { - } \quad \text { Adaptation of waste regulations to support CE. } \\
\text { - Allocation of dedicated funding towards the support of } \\
\text { CE implementation. }\end{array}$ \\
\hline $\begin{array}{l}\text { Luxembourg as a knowledge } \\
\text { capital and testing ground for } \\
\text { the Circular Economy }\end{array}$ & $\begin{array}{l}\text { - } \quad \text { Establishment of a materials within infrastructures inventory. } \\
\text { - } \quad \text { Innovate designs and usage models with higher material productivity. } \\
\text { - } \quad \text { Improve residual value of materials and components. } \\
\text { - } \quad \text { Material passports and/or material banking. } \\
\text { - } \quad \text { Modular designs. } \\
\text { - } \quad \text { Leasing of assets and equipment. }\end{array}$ \\
\hline
\end{tabular}

The most commonly presented indicators are the percentage of materials reused and/or recycled, resource efficiency, material circularity index and raw material productivity. Some of the most detailed publications provide action plans for each sector to follow and targets that need to be fulfilled under specific timetables, in order for the transition to a $\mathrm{CE}$ to be realized. The majority of the documents 
separate their action plans into different sectors or different operational levels and propose targets or actions specifically tailored to each sector. The most common points that can be found in the documents are initiatives such as more effective waste management and minimization, utilization of waste as resources in parallel industries, minimization of $\mathrm{CO}_{2}$ emissions under predefined time horizons and resource and energy efficiency. All of them state that waste prevention, design, reuse, repair, remanufacture, recycling, producer responsibility for reuse and recycling, recovering value from biological resources, energy recovery, and landfilling are main issues that need to be addressed. Most of the analyzed documents describe a vision or a concept conceived by the publishing authorities. However, achieving the transformation described in most of the analyzed documents can be difficult or even impossible without a specific and detailed plan, supported by legislation. A lot of documents highlight as challenges the need for increased resource efficiency, creation of a circular business environment, the lack of end-of-life practices, and the lack of co-operation and communication between small and medium-sized enterprises (SMEs) and research and development institutions.

When it comes to pavements however, no specific mentions can be found in the documents apart from the ones published by Highways England, the Dutch government, the German Federal Ministry for the Environment, Nature Conservation, Building and Nuclear Safety, and Platform CB'23 (The Netherlands). In addition, direct applicability to asphalt pavements of the approaches and indicators deployed for the building and construction sectors can be found in the published documents of the French Ministry of Ecology and Ministry of Economy and Finance, and the National Roadmap to positive impacts of Luxemburg. There are examples of CE implementation that entail the promotion of asphalt recycling, the attempt to change specifications that restrict the large scale recycling of asphalt, the common effort towards constructing and managing longer-lasting pavements and the plan towards the utilization of renewable energy sources for the production, construction and maintenance of asphalt pavements. Material banks and material passports, along with material flow tracking are proposed by these documents. The need for increased and monitored resource efficiency is highlighted as well as the need for a change in behavioral patterns that support leasing, modular designs and innovative thinking. Finally, to sum up, it can be said that in general, NRAs so far have not invested in producing roadmaps towards the implementation of CE.

\subsection{Analysis of the Questionnaire to NRAs}

All of the NRAs contacted are aware of the concept of CE and have at least minimal knowledge about what it represents. All but one of the NRAs were familiar with the most commonly known and easily applicable principles of the CE. Austria's and The Netherlands' NRAs seem to be the most informed in terms of $C E$ knowledge, exhibiting the highest number of $C E$ principles that they are familiar with. Among all the NRAs to which the questionnaire was sent, the most commonly known principles of CE are:

- Design out/minimize waste

- Use waste as a resource

- Preserve and extend what is already made (usually translated as "preventive maintenance")

When the NRAs were asked about which principles of CE were being implemented, Belgium, Norway and Lithuania replied that none of them are currently being implemented. However, among the remaining NRAs the most common answers that were received in terms of implemented CE principles were:

- Preserve and extend what is already made

- Design out/minimize waste

In reply to the question about practices that indicate the implementation of CE principles, Austria's NRA replied with specifications in guidelines and internal planning manuals, similar to Germany's NRA which is following waste legislation (Kreislaufwirtschaftsgesetz national law of EU directive 
2008/98/EG). Belgium's, United Kingdom's and Denmark's NRAs stated that they are preserving the road condition and extending its service life, by performing preventive maintenance. In this way they can maintain the serviceability levels of their road assets at a desirable level for prolonged periods of time, avoiding in this way extensive maintenance actions. Lithuania is testing waste materials in trial sections in order to promote the use of waste as a resource, while Slovenia and Slovakia are removing restrictions on asphalt recycling. Finally, The Netherlands are incorporating recycled materials in asphalt mixtures and extensively perform periodic preventive maintenance to extend the lifecycle of the asphalt pavements. Thus, the most commonly applied practices that indicate the implementation of some of the aforementioned principles are:

- Removing restrictions on asphalt recycling to minimize waste

- Extending the service life of asphalt pavements, usually by preventive maintenance

- Testing waste materials for potential utilization as resources in asphalt pavements

The concept of CE is not totally new, as described in the introduction, and hence, some of its characteristics have already been practiced by NRAs. Aspects such as recycling, resource efficiency, and utilization of waste materials in foundation layers are not new topics and have been implemented by NRAs for many years. These practices are in line with the principles of CE, yet some of the NRAs do not project them as "supporting the CE". In other words, although some NRAs might have stated that no specific principles of $C E$ are being implemented, they still recycle and try to use resources efficiently while extending the service life of their assets. This turns out to be a matter of definitions. Some countries have legislation or targets for using waste in foundations and are thus practicing elements of $\mathrm{CE}$, although they do not use the term itself.

The challenges of implementing CE practices, that the NRAs stated exist, are the inadequate technical and mechanical performance of recycled materials, technological and administrative limitations, and the difficulty of avoiding downgrading of the recycled materials. When it comes to $\mathrm{CE}$ indicators and/or metrics, Austria's NRA is using the end of life recycling input, while Germany's the amount of reuse of RA in the production of new hot mix asphalt. It is worth noting here that these indicators are not CE specific. In other words, although the NRAs were asked if they are utilizing $\mathrm{CE}$ indicators, they focused their replies on the aforementioned indicators that mainly represent the percentage of reclaimed asphalt reused. This is something that strengthens the initial assertion that recycling asphalt is the principal method of implementing CE in asphalt pavements.

The NRAs state that the challenges encountered in developing or implementing circularity metrics are budget restrictions, along with the lack of clear rules/legislation to support this effort. Finally, the only NRA that has officially published a roadmap or a strategy towards the implementation of CE is Highways England (UK). However, Austria's NRA is following the national sustainability strategy, Belgium's has adopted the circular roadmap published by "Circular Flanders", and The Netherlands' is following the guidelines towards circularity, recently published by Platform CB23. The challenges the remaining NRAs are encountering in the development of a CE implementation strategy are the lack of common points of view, which hinders combined efforts with involved stakeholders, the lack of incentives and the fact that the existing incentives for the reuse of asphalt are mostly industry driven.

\subsection{Analysis of the Web Search: NRAs and CE Communication}

As can be observed in Table 3, only four out of ten NRAs investigated were attempting to communicate the ways that $\mathrm{CE}$ principles are projected through their operational patterns. The only NRA that has published an "Approach and Route Map" towards CE is Highways England, in which future visions and plans that are aligned with the implementation of CE are described. Germany's NRA seems to be on a similar path since it has developed a plan called Climate Action Program 2030, which contributes towards the implementation of more circular and sustainable practices. In addition to that, practices relevant to the preservation of resources, maximization of resource efficiency, 
resource cycle management and bio economy are strongly supported and communicated. It can be seen, however, that the majority of the investigated NRAs are publishing sustainability reports and communicating their plans in terms of sustainability, but CE is still not a matter that seems to be a object of their full attention. Thus, there is still a significant opportunity for knowledge development in the field of road engineering agencies and on the topic of CE.

Table 3. Ways that NRAs are implementing and communicating CE.

\begin{tabular}{cc}
\hline National Road Authority per Country & CE Implementation Plan and Communication \\
\hline Austria (ASFiNAG) & Sustainability strategies and reports/no specific mention \\
of CE
\end{tabular}

\section{Discussion and Conclusions}

Within the perspective of a road engineering industry, based upon the principles of sustainability and $\mathrm{CE}$, the approaches in constructing and managing asphalt pavements play a key role. Lately, NRAs are directly or indirectly being pushed towards implementing more sustainable and circular operational patterns. This is achieved either by complying with existing legislations, or by trying to promote a more sustainable way of doing business out of environmental, social or mostly economic concerns.

As can be seen from the analysis, the majority of the NRAs are not currently communicating any CE related advances or implementation actions. More focus should be given to the communication aspect of CE since it is an aspect that can significantly influence consumer behavior [84]. Moreover, to detect the CE implementation paths of the NRAs, a questionnaire was sent to them. It seems that all the NRAs are aware of the concept of CE and most of them are aware of most of the principles it represents, but the majority are not implementing them thoroughly. Most of the NRAs replied that in their attempt to implement the CE principles, they prioritize the "designing out" of the waste in their products, they move towards the utilization of higher reclaimed asphalt percentages, and try to prolong the life of their assets by conducting preventive maintenance.

Some of the NRAs stated that they are not implementing such circular practices. However, they do recycle, implement preventive maintenance regimes, and sometimes utilize waste materials as resources within the asphalt pavements that they construct and manage. This means that all of the NRAs that have completed the questionnaire do, in some way, implement practices that are aligned with the 
principles of CE. However, it is worth emphasizing that although the questionnaire was generic in the context of CE and its implementation, the majority of the NRAs replied that the most commonly used CE principle is the use of waste as resource, and thus, the focus of the NRAs was found mainly in asphalt recycling. This could lead to the conclusion that more people with specialization in CE should be operating within the NRAs providing more insights and knowledge in terms of CE implementation for a more holistic approach. In addition, following also the distinction of the schools of thought that was presented in Chapter 2.1, it can be deduced that all the recorded efforts of the NRAs so far are focusing on the aspects of the restorative economy. For a more holistic approach, the NRAs could push towards implementing CE principles that could fulfill aspects of the collaborative and sharing economy as well.

Recommendations and best practices that would provide NRAs with a more sustainable and circular operating angle have been presented through the documentation of two relevant documents. They focus on green public procurement for road design, construction, and maintenance, and circular principles for building design, respectively. As it can be easily deduced, the former presents recommendations and/or practices for roads specifically, while the latter is mostly focused on the building sector. However, road pavements, their construction, use and maintenance can be integrated in the broader sense of the building sector and, hence, recommendations can be extracted that are easily transferable to field of road pavements. The most immediate actions that NRAs could undertake in order to move in this direction are:

- The rethinking of their designs, minimizing the use of materials and improving the durability of the asphalt pavements while allowing their reuse, repair, recycle or recovery.

- The research and development of alternative, more environmentally friendly, construction and maintenance methods.

- The utilization of soil and waste during the construction and maintenance phases as useful materials.

- Development of end of life strategies, focusing on the possibility of closed loop approaches and/or upcycling.

However, NRAs have identified a plethora of challenges in the implementation of a holistic CE approach. The need for increased resource efficiency, creation of a circular business environment, the lack of end-of-life practices, and the lack of co-operation and communication between SMEs and research and development institutions, are slowing the $\mathrm{CE}$ transition. Moreover, the inadequate technical and mechanical performance of recycled materials, technological and administrative limitations, and the difficulty of avoiding downgrading the recycled materials, are areas of concern for the NRAs. Finally, budget restrictions, the lack of clear rules/legislation to support CE, the lack of incentives, and the fact that the existing incentives for the reuse of asphalt are mostly industry driven, constitute challenges in the implementation of CE principles by the NRAs.

NRAs could work towards tackling these challenges and developing frameworks for the holistic implementation and communication of CE. This could help to monitor and evaluate the progress that is being made and finally develop a feasible approach towards circular operational tactics.

Finally, it is worth mentioning that, to our knowledge, this is the first published paper to explore the knowledge and interest of NRAs in the topic of CE and its implementation and communication. Thus, a suggestion for future research is to collect data from more NRAs in order for a more spherical picture to be developed. The results of the specific study are limited to the NRAs that have been investigated and hence, do not clearly depict the whole situation on a fully European scale.

Author Contributions: Conceptualization, K.M., G.D.M., and D.L.P.; Methodology, K.M.; Validation, K.M.; Formal Analysis, K.M.; Investigation, K.M.; Data Curation, K.M.; Writing-Original Draft Preparation, K.M., T.P. and G.D.M.; Writing—Review and Editing, K.M., G.D.M., D.L.P., A.J.D.B.C., E.K., B.K., T.P.; Visualization, K.M. and T.P.; Supervision, T.P., D.L.P. and G.D.M.; Project administration, D.L.P. and G.D.M.; Funding acquisition, D.L.P. and G.D.M. All authors have read and agreed to the published version of the manuscript. 
Funding: The SMARTI ETN project has received funding from the European Union's Horizon 2020 Program under the Marie Curie-Skłodowska actions for research, technological development, and demonstration, under Grant No. 721493. The research presented in this paper was carried out as part of the SMARTI ETN ESR10: "LCSA4TRANSPORT". This paper summarizes part of the results of "PAVEMENT LCM: a complete package for Life Cycle Management of green asphalt mixtures and road pavement", a research project of the cross-border funded joint research programme "CEDR Call 2017: New Materials". The project has received funding from the CEDR Transnational Research Programme and the participating National Road Authorities for this call, are Austria, Belgium-Flanders, Denmark, Germany, Netherlands, Norway, Slovenia, Sweden and the United Kingdom.

Conflicts of Interest: The authors declare no conflict of interest.

Disclaimer: The contents of this paper reflect the views of the authors, who are responsible for the facts and the accuracy of the data presented. Any inclusion of manufacturer names, trade names, or trademarks is for identification purposes only and is not to be considered an endorsement. Moreover, this paper does not constitute a standard, specification, or regulation.

\section{Appendix A}

1. Are you familiar with the concept of Circular Economy and its principles?

\begin{tabular}{|l|l|}
\hline Yes & No \\
\hline
\end{tabular}

- If yes, which principles of Circular Economy are you familiar with? (tick as many as needed)

- Design out/minimize waste

- Use waste as resource (recycle, reuse)

- Prioritize regenerative resources

- Preserve and extend what is already made

- Other, please specify:

2. Which of those principles have already been introduced within established pavement life cycle management practices?

- Design out/minimize waste

- Use waste as resource (recycle, reuse)

- Prioritize regenerative resources

- Preserve and extend what is already made

- Other, please specify:

3. Which practices are you using to implement those principles for Circular Economy?

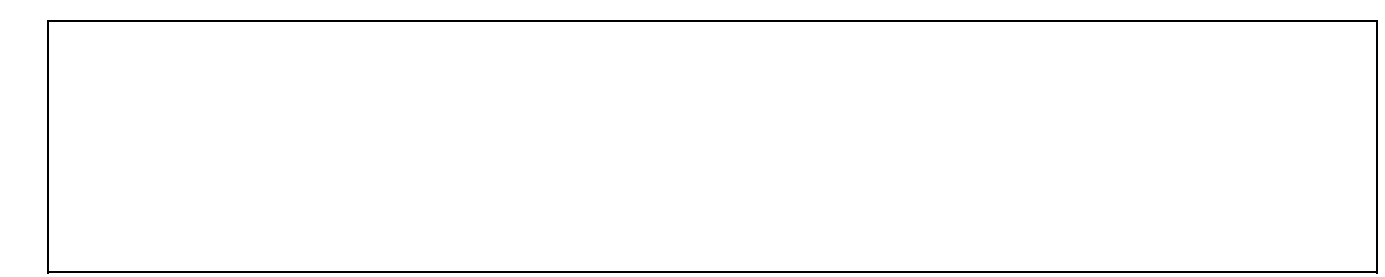

4. If these principles are currently not implemented into practices, which reasons/challenges are impeding it? Is there a future strategy to implement them? 


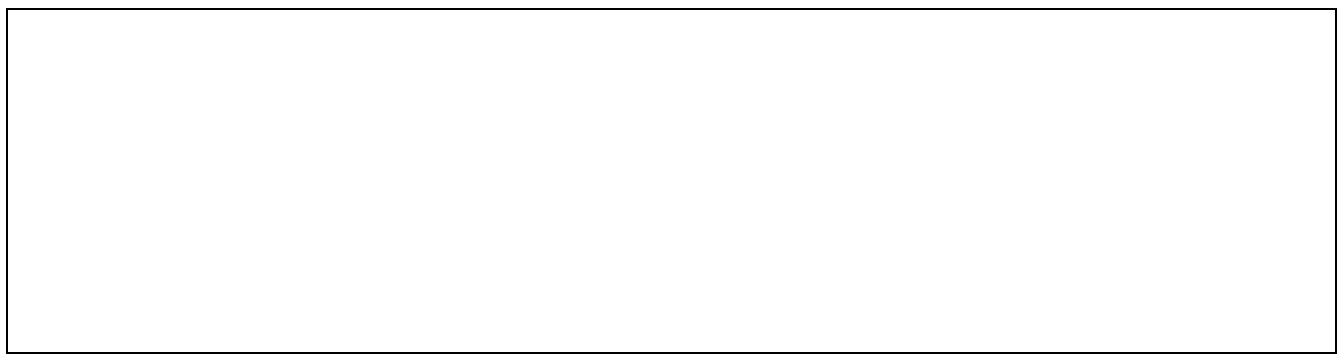

5. Are there any current metrics/indicators to assess the level of circularity of these practices and/or the pavement management process?

\begin{tabular}{|l|l|}
\hline Yes & No \\
\hline
\end{tabular}

- If yes, which are these metrics/indicators?

- Product Material Circularity Index (MCIP) [Ellen MacArthur foundation (EMF)]

- Company Material Circularity Index (MCIC) [Ellen MacArthur foundation (EMF)]

- End of Life recycling input rate [Available in the EU's Raw Material Scoreboard and in EC Monitoring framework for the CE (under development)]

- Resource Efficiency [EU Resource Efficiency scoreboard (EURES)]

- Other, please specify:

6. If no, which reasons/challenges are impeding their development? Is there a future strategy to define them?

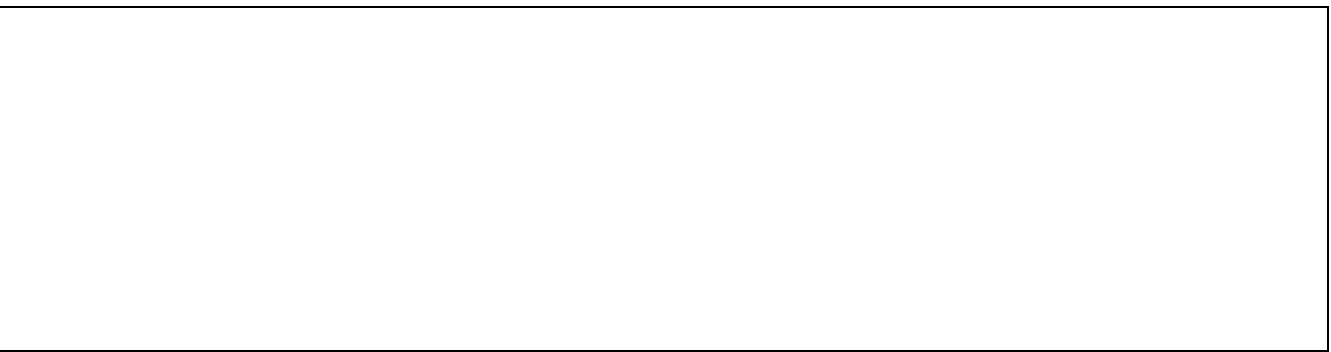

7. Has a "Roadmap" towards Circular Economy been produced/published, to achieve more sustainable and circular management of asphalt pavements?

\begin{tabular}{|c|c|}
\hline Yes & No \\
\hline
\end{tabular}

8. If yes, could you please provide us with a copy or link to find it

9. If not, which are the current challenges, posing as obstacles towards the production of such a roadmap? Is there a future strategy to produce one?

\section{References}

1. Bringezu, S.; Schütz, H.; Steger, S.; Baudisch, J. International comparison of resource use and its relation to economic growth: The development of total material requirement, direct material inputs and hidden flows and the structure of TMR. Ecol. Econ. 2004, 51, 97-124. [CrossRef] 
2. Richard, C.; Amit, P. Exploiting Natural Resources: Growth, Instability, and Conflict in the Middle East and Asia; The Henry L. Stimson Center: Washington DC, USA, 2009.

3. Barbier, E.B. The Concept of Sustainable Economic Development. Environ. Conserv. 1987, 14, $101-110$. [CrossRef]

4. Purvis, B.; Mao, Y.; Robinson, D. Three pillars of sustainability: In search of conceptual origins. Sustain. Sci. 2018, 14, 681-695. [CrossRef]

5. European Comission. European Commission: Roadmap to a Resource Efficient Europe; European Comission: Brussels, Belgium, 2011.

6. Ecorys. Resource Efficiency in the Building Sector: Final Report; European Comission: Brussels, Belgium, 2014.

7. Ellen MacArthur Foundation. Towards a Circular Economy: Business Rationale for an Accelerated Transition; Ellen MacArthur Foundation: Cowes, UK, 2015; pp. 4-20. Available online: https://www.ellenmacarthurfoundation. org/assets/downloads/TCE_Ellen-MacArthur-Foundation-9-Dec-2015.pdf (accessed on 10 June 2020).

8. Mantalovas, K.; Di Mino, G. The sustainability of reclaimed asphalt as a resource for road pavement management through a circular economic model. Sustainability 2019, 11, 2234. [CrossRef]

9. Mantalovas, K.; Di Mino, G. Integrating circularity in the sustainability assessment of asphalt mixtures. Sustainability 2020, 12, 9-12. [CrossRef]

10. Ma, S.; Hu, S.; Chen, D.; Zhu, B. A case study of a phosphorus chemical firm's application of resource efficiency and eco-efficiency in industrial metabolism under circular economy. J. Clean. Prod. 2015, 87, 839-849. [CrossRef]

11. Bai, Y. An exploration of firms' awareness and behavior of developing circular economy: An empirical research in China. Resour. Conserv. Recycl. 2014, 87, 145-152.

12. Mathews, J.A.; Tan, H. Progress toward a circular economy in China: The drivers (and inhibitors) of eco-industrial initiative. J. Ind. Ecol. 2011, 15, 435-457. [CrossRef]

13. Zhijun, F.; Nailing, Y. Putting a circular economy into practice in China. Sustain. Sci. 2007, 2, 95-101. [CrossRef]

14. Frodermann, L. Exploratory Study on Circular Economy Approaches; Springer Science and Business Media LLC.: Berlin, Germany, 2018.

15. Meadows, D.H.M. The Limits to Growth. Club Rome 1972, 102, 27.

16. Lomborg, B. Environmental Alarmism, Then and Now; Foreign affairs (Council on Foreign Relations): Washington DC, USA, 2012; pp. 1-8. Available online: https://www.researchgate.net/publication/297823867_ Environmental_Alarmism_Then_and_Now_The_Club_of_Rome $\backslash T 1 \backslash$ textquoterights_Problem-and_Ours (accessed on 10 June 2020).

17. Bicket, M.; Guilcher, S.; Hestin, M.; Hudson, C.; Razzini, P.; Tan, A.; ten Brink, P.; van Dijl, E.; Vanner, R.; Watkins, E. Scoping Study to Identify Potential Circular Economy Actions, Priority Sectors, Material Flows and Value Chains; Publications office of the European Union: Luxemburg, 2014.

18. Gregson, N.; Crang, M.; Fuller, S.; Holmes, H. Interrogating the circular economy: The moral economy of resource recovery in the EU. Econ. Soc. 2015, 44, 218-243. [CrossRef]

19. Boulding, K.E. The Economics of the Coming Spaceship Earth in Environmental Quality Issues in a Growing Economy; Daly, H.E., Ed.; Johns Hopkins University Press: Baltimore, MD, USA, 1966; pp. 4-14.

20. DOBBS, C.G. Silent Spring. In Forestry: An International Journal of Forest Research; Oxford University Press: Oxford, UK, 1963; Volume 36, pp. 195-198. [CrossRef]

21. Ellen MacArthur Foundation. Towards the Circular Economy-Economic and Business Rationale for an Accelerated Transition; Ellen MacArthur Foundation: Cowes, UK, 2013; Volume 1, pp. 1-96. Available online: https://www.ellenmacarthurfoundation.org/assets/downloads/publications/ EllenMacArthur-Foundation-Towards-the-Circular-Economy-vol.1.pdf (accessed on 10 June 2020).

22. Ellen MacArthur Foundation. Cities in the Circular Economy: An Initial Exploration; Ellen MacArthur Foundation: Cowes, UK, 2017; pp. 4-14. Available online: https://www.ellenmacarthurfoundation.org/ assets/downloads/publications/Cities-in-the-CE_An-Initial-Exploration.pdf (accessed on 10 June 2020).

23. Ellen MacArthur Foundation; GRANTA, LIFE. Circularity Indicators-An Approach to Measuring Circularity: Methodology; Ellen MacArthur Foundation: Cowes, UK, 2015; pp. 7-12. 
24. Ellen MacArthur Foundation. Towards Circular Economy: Opportunities for the Consumer Goods Sector; Ellen MacArthur Foundation: Cowes, UK, 2013; Volume 2, pp. 6-80. Available online: https://www. ellenmacarthurfoundation.org/assets/downloads/publications/TCE_Report2013.pdf (accessed on 10 June 2020).

25. Tran, T.; Park, J.Y. Development of a novel co-creative framework for redesigning product service systems. Sustainability 2016, 8, 434. [CrossRef]

26. Goedkoop, P.J.M.; van Halen, M.J.; te Riele, C.J.G.; Rommens, H.R.M. Product Service systems, Ecological and Economic Basics. Rep. Dutch Ministries Environ. Econ. Aff. 1999, 36, 1-122.

27. Clark, G.; Kosoris, J.; Hong, L.N.; Crul, M. Design for sustainability: Current trends in sustainable product design and development. Sustainability 2009, 1, 409-424. [CrossRef]

28. The British Standards Institution (BSI). Framework for Implementing the Principles of the Circular Economy in Organizations-Guide; BSI: London, UK, 2017.

29. Pearce, D.W.; Turner, R.K. Economics of Natural Resources and the Environment; Harvester Wheatsheaf: London, UK, 1990.

30. Ellen MacArthur Foundation. Towards the Circular Economy Volume 3: Accelerating the Scale-Up Across Global Supply Chains; Ellen MacArthur Foundation: Cowes, UK, 2014; pp. 1-64. Available online: https://www.ellenmacarthurfoundation.org/assets/downloads/publications/Towards-the-circulareconomy-volume-3.pdf (accessed on 10 June 2020).

31. Chen, C. Guidance on the conceptual design of sustainable product-Service systems. Sustainability 2018, 10, 2452. [CrossRef]

32. Stahel, W.R. The service economy: Wealth without resource consumption? Philos. Trans. R. Soc. A Math. Phys. Eng. Sci. 1997, 355, 1309-1319. [CrossRef]

33. Botsman, R.; Rogers, R. What's Mine Is Yours: The Rise of Collaborative Consumption; Botsman, R., Rogers, R., Eds.; HarperCollinsPublishers: New York, NY, USA, 2010; p. 304.

34. Hawken, P. The Ecology of Commerce: A Declaration of Sustainability; HarperCollinsPublishers: New York, NY, USA, 1993.

35. McDonough, W.; Braungart, M. Cradle to Cradle: Remaking The Way We Make Things; North Point Press: New York, NY, USA, 2002.

36. Llorach-Massana, P.; Farreny, R.; Oliver-Sola, J. Are cradle to cradle certified products environmentally preferable? analysis from an LCA approach. J. Clean. Prod. 2016, 113, 715-716. [CrossRef]

37. Montana, H.C.A. Bio-ID4S: Biomimicry in Industrial Design for Sustainability: An Integrated Teaching-and-Learning Method; VDM Verlag Dr. Müller: Saarbrücken, Germany, 2010.

38. De Pauw, I.C.; Karana, E.; Kandachar, P.; Poppelaars, F. Comparing biomimicry and cradle to cradle with ecodesign: A case study of student design projects. J. Clean. Prod. 2014, 78, 174-183. [CrossRef]

39. Reap, J.; Baumeister, D.; Bras, B. Holism, biomimicry and sustainable engineering. IMECE 2008, 42185, 423-431.

40. Kuo, N.W.; Hsiao, T.Y. An exploratory research of the application of natural capitalism to sustainable tourism management in Taiwan. J. Clean. Prod. 2008, 16, 116-124. [CrossRef]

41. Lovins, L.H.L.; Amory, B.; Paul, H. A road map for natural capitalism. Harv. Bus. Rev. 1999, 77, $145-158$. [PubMed]

42. Erkman, S. Industrial ecology: An historical view. J. Clean. Prod. 1997, 5, 1-10. [CrossRef]

43. Kagawa, S.; Hashimoto, S.; Managi, S. Special issue: Studies on industrial ecology. Environ. Econ. Policy Stud. 2015, 17, 361-368. [CrossRef]

44. Mantalovas, K. Interpreting life cycle assessment results of bio-asphalt pavements for more informed decision-making. In Pavement, Roadway, and Bridge Life Cycle Assessment 2020, Proceedings of the International Symposium on Pavement. Roadway, and Bridge Life Cycle Assessment 2020 (LCA 2020), Sacramento, CA, USA, 3-6 June 2020; Available online: https://www.researchgate.net/publication/342642405_Interpreting_life_cycle_ assessment_results_of_bio-recycled_asphalt_pavements_for_more_informed_decision-making (accessed on 30 July 2020).

45. Giani, M.I.; Dotelli, G.; Brandini, N.; Zampori, L. Resources, conservation and recycling comparative life cycle assessment of asphalt pavements using reclaimed asphalt, warm mix technology and cold in-place recycling. Resour. Conserv. Recycl. 2015, 104, 224-238. [CrossRef] 
46. Lo Presti, D. Allback2pave: Towards a sustainable recycling of asphalt in wearing courses. In Proceedings of the AIIT International Congress on Transport Infrastructure and Systems, Rome, Italy, 10-12 April 2017; pp. 109-117.

47. Chiu, C.-T.; Hsu, T.-H.; Yang, W.-F. Life cycle assessment on using recycled materials for rehabilitating asphalt pavements. Resour. Conserv. Recycl. 2008, 52, 545-556. [CrossRef]

48. Newcomb, D.E.; Ray, B.E.; Epps, J.A. Designing HMA Mixtures with High Rap Content: A Practical Guide; National Asphalt Pavement Association: Lanham, MD, USA, 2007.

49. Song, W.; Huang, B.; Shu, X. Influence of warm-mix asphalt technology and rejuvenator on performance of asphalt mixtures containing 50\% reclaimed asphalt pavement. J. Clean. Prod. 2018, 192, 191-198. [CrossRef]

50. Van Winkle, C.I. Laboratory and Field Evaluation of Hot Mix Asphalt with High Contents of Reclaimed Asphalt Pavement. Master's Thesis, University of Iowa, Iowa City, IA, USA, 2014.

51. Lu, D.X.; Saleh, M. Evaluation of Mechanical Properties of a New Warm-Mix Asphalt using Sylvaroad Additive. Athens J. Technol. Eng. 2017, 4, 83-96. [CrossRef]

52. Berg, A. Reports of the Finnish Environment Institute-Circular Economy for Sustainable Development; Finnish Environment Institute (SYKE): Helsinki, Finland, 2018.

53. Pérez-Acebo, H.; Linares-Unamunzaga, A.; Abejon, R.; Rojí, E. Research Trends in Pavement Management during the First Years of the 21st Century: A Bibliometric Analysis during the 2000-2013 Period. Appl. Sci. 2018, 8, 1041. [CrossRef]

54. Qiao, Y.; Dave, E.V.; Parry, A.; Valle, O.; Mi, L.; Ni, G.; Yuan, Z.; Zhu, Y. Life Cycle Costs Analysis of Reclaimed Asphalt Pavement (RAP) Under Future Climate. Sustainability 2019, 11, 5414. [CrossRef]

55. Asphalt Pavement Alliance. Recycling E Energy Reduction; Asphalt Pavement Alliance: Lanham, MD, USA, 2017; p. 2.

56. Williams, B.A.; Willis, J.R.; Ross, T.C. Asphalt Pavement Industry Survey on Recycled Materials and Warm-Mix Asphalt Usage: 2018, Information Series 138, 9th ed.; National Asphalt Pavement Association (NAPA): Greenbelt, MD, USA, 2019.

57. Noferini, L.; Simone, A.; Sangiorgi, C.; Mazzotta, F. Investigation on performances of asphalt mixtures made with Reclaimed Asphalt Pavement: Effects of interaction between virgin and RAP bitumen. Int. J. Pavement Res. Technol. 2017, 10, 322-332. [CrossRef]

58. Blasl, A.; Kraft, J.; Lo Presti, D.; Di Mino, G.; Wellner, F. Performance of asphalt mixes with high recycling rates for wearing layers. In Proceedings of the 6th Eurasphalt Eurobitume Congregation, Prague, Czech Republic, 30 June 2016.

59. European Commission (EC). European Resource Efficiency Platform (EREP)-Manifesto E Policy Recommendations; European Commission: Brussels, Belgium, 2012; pp. 1-16. Available online: https://ec.europa.eu/environment/ resource_efficiency/documents/erep_manifesto_and_policy_recommendations_31-03-2014.pdf (accessed on 10 June 2020).

60. Ghosh, S.K. Circular Economy: Global Perspective; Springer: Singapore, 2020.

61. PlatformCB23. Kernmethode Voor Het Meten Van Circulariteit in de Bouw; Platform CB'23: Delft, The Netherlands, 2019; Available online: https://platformcb23.nl/images/downloads/Platform_CB23_Core_method_for_ measuring_circularity_in_the_construction_sector_Version_1.0_July_2019.pdf (accessed on 10 June 2020).

62. European Commission (EC). Report from the Commission to the European Parliament, the Council, the European Economic and Social Committee and the Committee of the Regions on the Implementation of the Circular Economy Action Plan; European Commission: Brussels, Belgium, 2019.

63. Garbarino, E.; Quintero, R.R.; Donatello, S.; Caldas, M.G.; Wolf, O. Revision of Green Public Procurement Criteria for Road Design, Construction and Maintenance. Technical Report and Criteria Proposal; European Commision: Brussels, Belgium, 2016.

64. European Commission. Circular Economy Principles for Buildings Design; European Commission: Brussels, Belgium, 2019.

65. Chamber of Commerce and Industry of Slovenia. Ministry of the Environment And Spatial Planning, Republic of Slovenia, the Danube Goes Circular Transnational Strategy to Accelerate Transition Towards a Circular Economy in the Danube Region; Chamber of Commerce and Industry of Slovenia: Ljubljana, Slovenia, 2019.

66. Circular Flanders (Vlaanderen Circulair). Circular Flanders Together towards a Circular Economy-Kick-off Statement; Circular Flanders: Mechelen, Belgium, 2017. 
67. Be Circular, Gewestelijk Programma Voor Circulaire Economie; Government of the Brussels-Capital Region: Brussels, Belgium, 2016.

68. Pantsar, M. Leading the Cycle-Finnish Road Map to a Circular Economy 2016-2025; SITRA: Helsinki, Finland, 2016.

69. Ministry for Ecological and Solidary Transition. Transition, Ministry for an Ecological and Solidary, 50 Measures for a 100\% Circular Economy; Ministry for Ecological and Solidary Transition: Paris, France, 2018.

70. BMUB. German Resource Efficiency Programme II Programme for the Sustainable Use and Conservation of Natural Resources; Dispatch of Publications by the Federal Government: Rostock, Germany, 2016.

71. Hellenic Republic Ministry of Environment \& Energy. National Circular Economy Strategy; Ministry of Environment and Energy: Athens, Greece, 2018.

72. Ministero dell'Ambiente e della Tutela del Territorio e del Mare and Ministero dello Sviluppo Economico, Towards a Model of Circular Economy for Italy; Ministry of the Environment and Protection of the Territory and the Sea and Ministry of Economic Development: Rome, Italy, 2017.

73. Ministère de l'Economie. Ministère du Développement durable et des Infrastructures, and Luxinnovation, Luxembourg as a Knowledge Capital and Testing Ground for a Circular Economy; Ministère de l'Economie: Paris, France, 2015.

74. Republica Portuguesa. Leading the Transition-Action plan For Circular Economy in Portugal: 2017-2020; Ministry of Environment: Lisbon, Portugal, 2017. Available online: https://irculareconomy.europa.eu/platform/sites/ default/files/strategy___portuguese_action_plan_paec_en_version_3.pdf (accessed on 10 June 2020).

75. Šalamon, T.; Kos, I.; Novak, B.; Šprinzer, M.; Žurman, T. Strategy for the Transition to Circular Economy in Municipality of Maribor; European Commission: Brussels, Belgium, 2018; Volume 7, pp. 1-32.

76. Republika Slovenija Vlada Republike Slovenije. Roadmap Towards the Circular Economy in Slovenia; Republika Slovenija Vlada Republike Slovenije: Ljubljana, Slovenia, 2018.

77. Junta de Extremadura. Extremadura 2030 Estrategia de Economía Verde y Circular; Junta de Extremadura: Mérida, Spain, 2018; p. 353.

78. Catalunya, G.D.E. Impuls a l'economia verda i a l'economia Circular: Competitivitat, eficiènci i innovació D. Of. la General; Government of Catalonia: Barcelona, Spain, 2015.

79. Wijsmuller, J. Circulair Den Haag-Transitie naar een Duurzame Economie; City of the Hague: Hague, The Netherlands, 2018; Available online: https://denhaag.raadsinformatie.nl/document/6291317/1/RIS299353_Bijlage_1 (accessed on 10 June 2020).

80. Government of Netherlands. A Circular Economy in the Netherlands by 2050; Government of Netherlands: Amsterdam, The Netherlands, 2016; pp. 1-72.

81. Scottish Government. Making Things Last: A Circular Economy Strategy for Scotland; Scottish Government: Edinburgh, Scotland, 2016.

82. LWARB. London's Circular Economy Route Map; LWARB: London, UK, 2017.

83. AECOM and Atkins. Circular Economy Approach and Routemap; AECOM: Los Angeles, CA, USA, 2016.

84. Chamberlin, L.; Boks, C. Marketing approaches for a circular economy: Using design frameworks to interpret online communications. Sustainability 2018, 10, 2070. [CrossRef]

(C) 2020 by the authors. Licensee MDPI, Basel, Switzerland. This article is an open access article distributed under the terms and conditions of the Creative Commons Attribution (CC BY) license (http://creativecommons.org/licenses/by/4.0/). 